\title{
Realising lifelong learning for all: Governance and partnerships in building sustainable learning cities
}

\author{
Raúl Valdés-Cotera ${ }^{1} \cdot$ Mo Wang ${ }^{1} \cdot$ \\ Katharina Lunardon ${ }^{2}$
}

Published online: 2 June 2018

(C) Springer Science+Business Media B.V., part of Springer Nature, and UNESCO Institute for Lifelong Learning 2018

\begin{abstract}
All sectors of society play a key role in providing quality education and learning opportunities. As relevant learning opportunities are not restricted to the school system, ideally all citizens, at all levels of society and stages of life, should be engaged in learning activities. This strong message was brought to the attention of the education community in 1972 with the publication of Learning to be (Faure et al. 1972), ${ }^{1}$ also known as the Faure Report. Today, more than four decades later, the importance of this message is ever-increasing in the face of the complex and fast-changing nature of our world. Poverty, inequality, health threats and environmental degradation are just some of the challenges humanity is facing. Driven by the rapid development of technologies and innovations, which are reshaping life and work, the recognition is growing that lifelong learning - a holistic, inclusive and sector-wide approach to learning - is fundamental for a sustainable future of societies. Against this backdrop, the call is intensifying for reformative ways to provide attractive learning opportunities and implement sustainable education structures which equip citizens with knowledge, skills and attitudes to tackle the unprecedented challenges and recurring changes.
\end{abstract}

\footnotetext{
${ }^{1}$ Faure, E., Herrera, F., Kaddoura, A.-R., Lopes, H., Petrovsky, A. V., Rahnema, M. \& Ward, F. C. (1972). Learning to be. The world of education today and tomorrow. Paris: UNESCO. Retrieved 30 April 2018 from http://unesdoc.unesco.org/images/0000/000018/001801e.pdf.
}

Mo Wang

mw.wang@unesco.org

Raúl Valdés-Cotera

r.valdes-cotera@unesco.org

Katharina Lunardon

katharina.lunardon@hotmail.com

1 UNESCO Institute for Lifelong Learning, Hamburg, Germany

2 connexia - Gesellschaft für Gesundheit und Pflege, Bregenz, Austria 
Yet, in order to build a society capable of enabling and realising lifelong learning for all, as foreseen by the visionary authors of the Faure Report (Faure et al. 1972), a major shift is required in terms of current governance mechanisms and partnerships for education and learning. First and foremost, the central role of governments, who assume the primary responsibilities to guarantee citizens the right to education, is to ensure efficient, equitable and effective management of lifelong learning and to provide education for all. This task includes, among other adjustments, acting on the need to revisit the school-centred education culture which continues to view the school as the only education system and to incorporate the whole spectrum of learning systems and all types of learning (formal, non-formal and informal), to ensure the necessary coordination and synergy at both local and national levels (Torres 2011). ${ }^{2}$ This implies the establishment of a balanced, informed and collaborative institutional system, which enables multi-level governance, supports open decision-making, manages complexity and respects diversity. It also requires extensive participation of all relevant actors: families, teachers and educators, volunteers and community workers, policymakers and politicians, private companies, research communities, etc.

Despite being accommodated at national level, this approach is particularly relevant at local levels (regions, cities), where the development of abstract principles also leads to effective implementation of solutions. Benefiting from their compact nature, cities feature favourable settings for realising lifelong learning for all: possessing the advantages of proximity and scale, cities provide a framework to cultivate and enable access, collaboration and cooperation among education and learning providers and stakeholders (Yang 2012; Hirsch 1993). ${ }^{3}$

City governance and partnerships should offer operational strategies enabling citizens, as they take on their role as agents of change and transformation, to directly relate learning to their daily activities in their immediate environment and make informed judgements leading to conducive actions in daily life (Yang and Yorozu 2015). ${ }^{4}$ Cities worldwide have already been shown to find diverse ways of engaging a wide range of partners in the learning pathways of their citizens, such as community learning centres, learning festivals, etc. (Valdés-Cotera et al. 2015) ${ }^{5}$ and are paying special attention to the involvement of vulnerable groups in all phases of building a learning city: planning, implementation and monitoring.

\footnotetext{
${ }^{2}$ Torres, R. (2011). Lifelong learning: Moving beyond education for all. In J. Yang \& R. Valdés-Cotera (Eds), Conceptual evolution and policy developments in lifelong learning (pp. 40-50). Hamburg: UNESCO Institute for Lifelong Learning.

${ }^{3}$ Yang, J. (2012). An overview of building learning cities as a strategy for promoting lifelong learning. Journal of Adult and Continuing Education, 18(2), 97-113.

Hirsch, D. (1993). City strategies for lifelong learning. Paris: OECD Centre for Educational Research and Innovation.

${ }^{4}$ Yang, J. \& Yorozu, R. (2015). Building a learning society in Japan, the Republic of Korea and Singapore. Hamburg: UNESCO Institute for Lifelong Learning. Retrieved 1 March 2018 from http:// unesdoc.unesco.org/images/0023/002325/232547e.pdf.

${ }^{5}$ Valdés-Cotera, R., Longworth, N., Lunardon, K., Wang, M., Jo, S. \& Crowe, S. (2015). Unlocking the potential of urban communities: Case studies of twelve learning cities. Hamburg: UNESCO Institute for Lifelong Learning. Retrieved 30 April 2018 from http://unesdoc.unesco.org/images/0023/002345/ 234536e.pdf.
} 
With the aim to carry on the discussion of the first special issue of this journal on the development of inclusive, prosperous and sustainable urban communities (Osborne et al. 2013), ${ }^{6}$ this special issue deepens the understanding of building sustainable learning cities through governance and partnerships by showcasing a variety of themes, modalities and approaches in the development, management and maintenance of collaborative learning relations.

\section{A diversity of partnership-based governance approaches for learning cities}

The development of learning cities is a societal and trans-sectoral issue in terms of both its objectives and its concrete implementation. The five articles we present in this special issue capture different dimensions of a governance approach based on strong partnerships to support learning city initiatives in different parts of the world. The dimensions discussed include the field of education (sector-wide), its system and networks, as well as the involvement of relevant ministries and government agencies (inter-ministerial and inter-sectoral) and an understanding of lifelong learning, which is not only part of the daily life and work context of all citizens, but continuous in creating a synergy between government and diverse partners from a variety of sectors.

Our first article, entitled "Can learning in informal settings mitigate disadvantage and promote urban sustainability? School gardens in Washington, DC", contributes to understanding the relevance of informal settings to motivating young people to get involved in a city's sustainable efforts. The research carried out by Carley Fisher-Maltese, Dana R. Fisher and Rashawn Ray points to the potential of gardens to improve health and environmental issues in a school and in a community as a whole. But the authors also explain the barriers to engaging other partners such as families and communities in the process. If even the teachers frequently do not accompany their students to the garden for the lesson, the need to integrate the lesson into the curriculum fades.

In our second article, entitled "School-community learning partnerships for sustainability: Recommended best practice and reality", authors Leone Wheeler, Jose Roberto Guevara and Jodi-Anne Smith look at developments in Australia and identify partnerships as essential for the collaboration required in the building of sustainable learning cities. They view partnerships as a dynamic resource which reveals the underlying challenges of time management, funding skills and personnel involved, but also, based on experience and lessons learned, provides key recommendations going beyond a transactional arrangement. The authors identify four approaches of implementing learning partnerships between schools and communities and agree that a strong collaboration significantly helps to promote

\footnotetext{
${ }^{6}$ Osborne, M., Kearns, P. \& Yang, J. (Eds) (2013). Learning cities: Developing inclusive, prosperous and sustainable urban communities. International Review of Education: Journal of Lifelong Learning, 59(4), special issue.
} 
education and learning at school level and across the community, as well as cultivating environmental stewardship.

Our next article, "Fostering inclusive, sustainable economic growth and 'green' skills development in learning cities through partnerships", moves our attention to Hong Kong. Author Margarita Pavlova focuses on partnerships among institutions of technical and vocational education and training (TVET), industry, government and other partners in Hong Kong, which aim to stimulate the production and dissemination of knowledge and its application to the purpose of sustainable economic development and the "greening" of skills. The author's suggested model recognises the important role of governments in influencing the greening agenda in the learning cities initiative. She argues that an understanding of the complexity of partnership interlinkages, together with policy orientations and governance, helps cities to focus on specific strategies that support green growth by addressing the challenges of skills development.

The fourth article is entitled "Locating the fourth helix: Rethinking the role of civil society in developing smart learning cities". Authors Katarzyna Borkowska and Michael Osborne highlight the fact that each actor involved contributes to the development of a learning city according to their established function in society, with different degrees of relationship, intersection and synergy among them. The learning city approach captures the need of reorienting urban contexts through facilitating civic engagement, empowering citizens through lifelong learning and enhancing socially inclusive societies. Based on Glasgow's Future Cities Demonstrator Initiative in the United Kingdom (UK), which targeted the provision of new integrated services across the fields of health, transport, energy and public safety to improve the economy and citizens' wellbeing, the authors affirm that the transformative potential of new technologies should be established along with the models for social engagement. In this way, their article reinforces the need for a continuous dialogue between learning cities and smart cities initiatives.

Our final article, entitled "How collaborative governance can facilitate quality learning for sustainability in cities: A comparative case study of Bristol, Kitakyushu and Tongyeong", examines the nature of learning initiatives based on cooperative learning relationships such as participation, multi-stakeholder partnerships and coordination in the UK, in Japan, and the Republic of Korea, respectively. In response to the second point of the Guidelines for Building Learning Cities (UNESCO GNLC 2015a), "create a coordinated structure involving all stakeholders", authors Paul Ofei-Manu, Robert J. Didham, Won Jung Byun, Rebecca Phillips Premakumara Jagath Dickella Gamaralalage and Sian Rees point out how learning processes are related to governance mechanisms and institutional structures. In order to transform cities into learning cities, a change or improvement in the related governance structure is needed. The authors call for a collaborative structure by reinforcing the coordination of partnerships.

\footnotetext{
7 UNESCO GNLC (United Nations Educational, Scientific and Cultural Organization Global Network of Learning Cities) (2015a). Guidelines for building learning cities. Hamburg: UNESCO Institute for Lifelong Learning. Retrieved 10 April 2018 from http://unesdoc.unesco.org/images/0023/002349/ 234987e.pdf.
} 
Albeit having different focuses, cross-cuttingly, the five articles we present in this special issue universally contend that the participation and coordination of all partners involved in building a learning city is of major importance in meeting the diverse learning needs of all citizens and for providing learning opportunities that cultivate solutions and innovations to tackle the specific and diverse issues confronting cities for sustainable development (UNESCO GNLC 2015a).

\section{Building blocks of a sustainable learning city}

The United Nations 2030 Agenda for Sustainable Development, through its 17 goals and 169 targets (UN DESA DSD 2015), ${ }^{8}$ has set out an ambitious and transformative vision for a world that is sustainable in all aspects. As all of the Sustainable Development Goals (SDGs) include targets relevant to the national level, there is a crucial need to localise the SDGs and establish lifelong learning as the guiding principle for building more sustainable cities and achieving the 2030 agenda (UNESCO GNLC 2017). ${ }^{9}$

The Key Features of Learning Cities, (UNESCO GNLC 2015b, pp. 9-18) ${ }^{10}$ one of the guiding documents of the UNESCO Global Network of Learning Cities (GNLC), provide a tool to help localise the SDGs through a list of action areas that cities can follow in their quest for a sustainable future. As indicated in Table 1, each of the articles in this special issue presents insights and reflections on the key working areas of a learning city, which constitute the first five of the building blocks of a learning city in the Key Features of Leaning Cities (shown as columns in Figure 1).

Lined up together, these five articles present the diversity of learning environments that are fostered in a city, with a variety of specific learning aims and purposes. They show, in the pursuit of sustainable development, the necessities of extending learning opportunities inside and outside of the school system and the actions that can be taken to infuse learning into the entire life of a city.

From their various perspectives, the five articles focus on the ways of fostering collaborative learning relations both inter-sectorally and cross-sectorally, illustrating a paradigm shift which is inherently entailed by the multi-faceted nature and the breadth of sustainable development. Together, these articles lead to the sixth building block or column (shown on the far right of Figure 1), namely a concerted effort of enabling the provision of "a vibrant culture of learning throughout life".

\footnotetext{
${ }^{8}$ UN DESA DSD (United Nations Department of Economic and Social Affairs, Division for Sustainable Development) (2015). Sustainable Development Goals: 17 goals to transform our world. United Nations Sustainable development knowledge platform [online resource]. Retrieved 6 May 2018 from https:// sustainabledevelopment.un.org/.

9 UNESCO GNLC (2017). Learning cities and the SDGs: A guide to action. Hamburg: UNESCO Institute for Lifelong Learning. Retrieved 30 April 2018 from http://unesdoc.unesco.org/images/0026/ 002604/260442e.pdf.

${ }^{10}$ UNESCO GNLC (2015b). UNESCO Global Network of Learning Cities: Guiding documents. Hamburg: UNESCO Institute for Lifelong Learning. Retrieved 10 April 2018 from http://uil.unesco.org/ fileadmin/keydocuments/LifelongLearning/learning-cities/en-unesco-global-network-oflearning-citiesguiding-documents.pdf.
} 


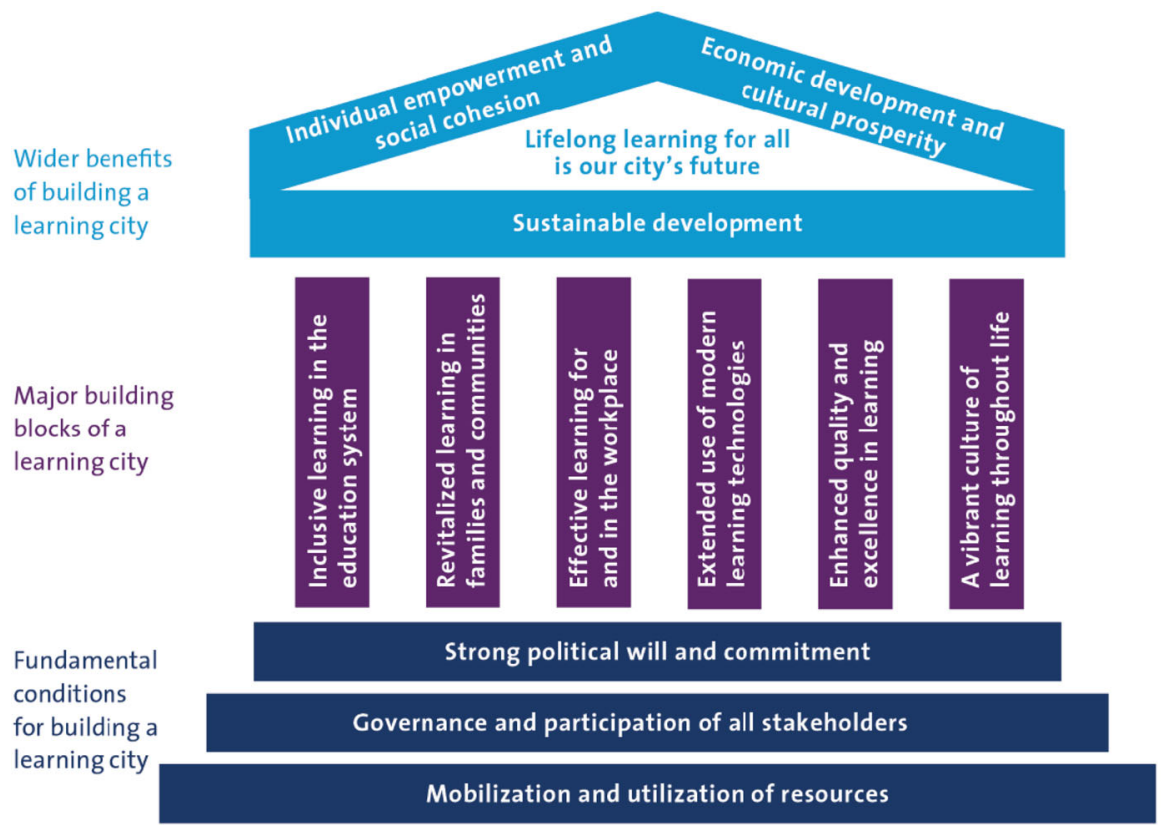

Figure 1 The framework of the Key Features of Learning Cities Source: UNESCO GNLC (2015b, p. 11)

Table 1 Building blocks of learning cities related to the articles in this special issue

\begin{tabular}{lc}
\hline Building block of a learning city & Title of article \\
\hline $\begin{array}{l}\text { Promoting inclusive learning in the } \\
\text { education system }\end{array}$ & $\begin{array}{c}\text { Can learning in informal settings mitigate disadvantage and } \\
\text { promote urban sustainability? School gardens in Washington, } \\
\text { DC }\end{array}$ \\
$\begin{array}{c}\text { Revitalising learning in families } \\
\text { and communities }\end{array}$ & School-community learning partnerships for sustainability: \\
Facilitating effective learning for & Fostering inclusive, sustainable economic growth and "green" \\
and in the workplace & skills development in learning cities through partnerships \\
Extending the use of modern & Locating the fourth helix: Rethinking the role of civil society in \\
learning technologies & developing smart learning cities \\
Enhancing quality and excellence & How collaborative governance can facilitate quality learning for \\
in learning & sustainability in cities: A comparative case study of Bristol, \\
& Kitakyushu and Tongyeong
\end{tabular}

As guest editors of this special issue, we hope that readers will benefit from the concrete examples and insightful reflections on the learning cities' approach to sustainable development, and perhaps be able to apply some of them to their contexts. 


\section{The authors}

Raúl Valdés-Cotera is a Senior Programme Specialist at the UNESCO Institute for Lifelong Learning (UIL) in Hamburg, Germany, and Programme Manager of the UNESCO Global Network of Learning Cities (GNLC). Raúl holds an MBA and a PhD in Education. For over fifteen years, he has been working in international organisations in the field of lifelong learning and adult learning and education. He has led various research and advocacy projects such as the Conceptual Evolution and Policy Developments in Lifelong Learning (editor, with J. Yang, 2011), the Glossary for Adult Education in Latin America and the Caribbean (2013), the Public Policy Analysis in Basic Education for Youth and Adults (2015), Unlocking the Potential of Urban Communities. Case Studies of Twelve Learning Cities (editor, with N. Longworth and others (2015) and Entrepreneurial Learning City Regions (editor, with J. James and others, 2018).

Mo Wang works for the coordination team of the UNESCO Global Network of Learning Cities (GNLC), as Programme Specialist at the UNESCO Institute for Lifelong Learning (UIL) in Hamburg, Germany. She has worked as a core team member for developing key concept and outcome documents of the project for implementing lifelong learning at local level, such as the Guidelines for Building Learning Cities and Unlocking the Potential of Urban Communities: Case Studies of Twelve Learning Cities. She is also the main workforce to develop video tutorials on building learning cities. Her main research interests are lifelong learning governance, non-formal learning in the workplace, and intercultural comparative study in the context of lifelong learning implementation. She is currently engaged in her PhD study at Hamburg University, Germany, on the topic of non-formal learning for the third age.

Katharina Lunardon works as an Education Manager for an education and consultancy company in Bregenz, Austria, which aims to connect various partners in the field of care and nursing, and is specialised in providing support, education and training for professionals and individuals working in the field of care. Previously, she worked as an Assistant Professor at the Institute for Educational Sciences, University of Innsbruck, Austria, and in 2015 jointly developed the UNESCO Global Network of Learning Cities (GNLC) further with her colleagues at the UNESCO Institute for Lifelong Learning (UIL). She is particularly interested in urban learning spaces, transitions from educational institutions to working life and vice-versa, workplace learning, and the importance of creativity for change. 